\title{
An Evaluative Study for Egyptian Primary School Textbooks (Connect 1: A case study)
}

Prof. Heba M.Mohamed

Faculty of Education, Beni Suef University

\begin{abstract}
:
The present study aimed to investigate the appropriateness of Egyptian primary schools' textbook "Connect 1" from teachers' perspectives. For this purpose, 30 male and female experienced English language teachers were randomly selected from different primary schools in Beni Suef, Egypt. They were chosen based on the availability sampling method. The evaluation of the textbook was conducted quantitatively through a 4-point Likert scale questionnaire which was developed by the researcher. The textbook evaluation scheme contained 27 items which relied upon seven main criteria namely a) layout and design, b) subject and content, c) vocabulary, d) grammar, e) phonetics, f) activities, and g) skills. The results indicated that there was an incongruity between the presumed educational purposes, the teachers and learners' needs. It is believed that the results of the study could provide intriguing hints for the curriculum designers and materials developers to think of adapting the available materials or adopting an alternative textbook which contains an organized layout, useful and real-life subjects, contents, relevant and appropriate vocabulary, grammar and phonetics, relevant skills and activities, and corresponds to teachers' and learners' emerging needs.
\end{abstract}

Keywords: Textbook evaluation, Curriculum designers, Material developers. 


\section{on Teaching, Learning and Education}

\section{Introduction}

Teaching English language is worth as far as it is the main language of international communication. The teaching-learning process can be influenced by different factors that are related to teaching materials, students and teachers. Teaching materials are instruments that serve teachers and students to complete courses. They are the most tangible and visible aspects of curriculum and syllabus because they put the specific and practical elements of a syllabus. English school textbooks are reckoned to be the most relevant source of learning English worldwide, which function as a guide for learners and instructors making them engaged in practices and make both the teaching and learning activities to thrive.

Riazi (2003) argued that in the context of second/foreign language classroom, textbook is the second important factor after the role of teacher. Moreover, Garinger (2001) claimed that textbooks have significant effects on language learning processes in classrooms. According to Tomlinson (2011), a textbook is defined as a book which establishes the basic resources for a language-learning course.

According to Litz (2001), in the case of teaching (ELT) programs, textbooks have been perceived as the preliminary requirements in accomplishing the students' purposes and needs. In order to achieve the principal objectives of learning a second/foreign language, teachers should select the most appropriate textbooks that adjust the criteria, teachers' and learners' specific situations, and also their purposes and needs. However, Ramzjoo (2010) argued that in some settings, the majority of teachers are not free to choose their own textbooks. They should choose the textbooks which have been suggested to them.

In addition, Abdelwahab (2013) claimed that using a textbook in a program "can guarantee that students in different classes will receive a similar content and therefore, can be evaluated in the same way" (p. 55). Richards (2001) also highlighted the critical role of textbooks claiming that since textbooks provide structure and a syllabus, learning might not have any impact if the teaching course doesn't contain textbooks. With regard to the benefits and harms of using textbooks in the classrooms, there have been controversial claims. In this line, Garinger (2002) argues that instructors should consider the appropriate use of textbooks as well as learners' specific needs and purposes.

A very important professional activity for all EFL teachers is the ability to evaluate teaching materials effectively. Today, there is a wealth of EFL materials available, with hundreds of new, commercially available titles appearing every year. Teachers or course organizers are often under considerable professional and financial pressure to select a course book for an ELT program that will then become the textbook for years to come. Moreover, materials are usually seen as being the core of a particular program and are the most visible representation of what happens in the classroom. 


\section{3rd International Academic Conference on Teaching, Learning and Education}

The evaluation of current materials, therefore, deserves serious consideration since an inappropriate choice may waste funds and time and has a demotivating effect on students and possibly teachers. Another reason for textbook evaluation is the fact that it can be very useful in teacher development and professional growth. Ellis (1997) believe that textbook evaluation helps teachers move beyond impressionistic assessments and helps them to get useful, accurate, systematic, and contextual insights into the overall nature of textbook material. Textbook evaluation can also be a valuable part of teacher training programs since it serves the purpose of making teachers aware of important features to look for in textbooks while familiarizing them with a wide range of published language instruction materials.

\section{The Problem}

The researcher made some interviews with teachers of first year primary school; they confirmed that the textbook content is very long. It consisted of nine units in each term; there are a lot of difficult words and sounds in this textbook.

\section{Aim of the Study}

The present study aimed at evaluating 'first year primary textbook (Connect 1) in terms of its appropriateness for Egyptian students. It endeavored to find out whether or not the series can satisfy the students' needs and to see if the teachers are satisfied with the series and its feedback. Specifically, the study aims to evaluate the suitability of "Connect 1 " for Egyptian primary school pupils in terms of:

1) layout and design.

2) subject and content.

3) vocabulary items.

4) grammar.

5) phonetics.

6) activities.

7) language skills.

\section{Questions}

The study addresses the following questions:

1) To what extent is "Connect 1" appropriate for Egyptian primary school pupils in terms of layout and design?

2) How is "Connect 1" appropriate for Egyptian primary school pupils in terms of subject and content?

3) How far is "Connect 1" appropriate for Egyptian primary school pupils in terms of vocabulary items?

4) Is "Connect 1" appropriate for Egyptian primary school pupils in terms of grammar?

5) To what extent is "Connect 1" appropriate for Egyptian primary school pupils in terms of phonetics? 


\section{on Teaching, Learning and Education}

6) How far is "Connect 1" appropriate for Egyptian primary school pupils in terms of activities?

7) Is "Connect 1" appropriate for Egyptian primary school pupils in terms of language skills?

\section{Significance}

It is only recently that textbooks are being systematically evaluated in Egypt. The results of this study would be significant to all that are in the process of foreign language learning or teaching (FLL, SLT, or FLT).

The outcomes of this study can help teachers decide what to do in their classes in terms of presentation, procedure and evaluation of students' learning. The results of the study would be helpful not only to teachers and administrators, but also to material developers and syllabus planners.

\section{Literature Review}

\section{The Roles of Textbooks}

Textbooks are key resources for the students to learn the necessary content expected on a given program. For teachers, textbooks are most important resources to achieve aims of a textbook. They also support less experienced teachers as a source of ideas and tasks. Therefore, textbooks help to save time, to direct and present a lesson properly and easily, to guide discussion and to make learning better organized and faster (Tok, 2010). Teaching materials are the most practicable features of course's syllabus /curriculum. Many scholars and teachers believe that after the role of teacher, textbook is the second important factor in language learning classrooms (Riazi, 2003).

As far as teachers use teaching materials to their teaching learning process, they are expected to evaluate the material in order to provide better instructional material for their specific learners. Thus, their views on the usefulness and effectiveness of a certain teaching material are relevant to identify the merits and demerits of the material (Tok, 2010).

Ahour, Towhidiyan, and Saeidi (2014) claimed that textbooks are considered as the main sources of learning which help students to accomplish their needs and objectives. Ahour and Ahmadi (2012) mentioned the role of textbook as a means of gaining knowledge and information and argued that "textbooks are the main sources that convey the knowledge and information to the learners in an easy and organized way" (p. 176). 


\section{3rd International Academic Conference on Teaching, Learning and Education}

\section{Reasons for Textbook Evaluation}

Evaluating EFL materials is essential for teachers and material writers to modify existing teaching material to plan courses, and manage learning activities. Material evaluation is needed to identify particular strengths and weaknesses of textbooks which are already in use. Such activities also permit teachers to make optimum use of their strong points and strengthen the weaker areas by adapting and substituting materials from other materials (Tok, 2010).

Based on the works of many researchers there are many various reasons for evaluating textbooks. For instance, Littlejohn (2011) claimed that "materials analysis and evaluation enable us to look inside the materials and to take more control over their design and use" (p. 183). Evaluation helps teacher to be knowledgeable of the organizational origins of the materials and also to keep up with progresses in the field of language learning and teaching and consequently to adjust materials realistically (Ahour, Towhidiyan, \& Saeidi, 2014). In this regard, McDonough and Shaw (2003,) mentioned the role of evaluation as "a useful process in its own right" (p. 60).

According to Ellis (1997) there are three different kinds of material evaluation: 1) preuse, 2) in-use, and 3) post-use. The 'pre-use' or 'predictive' evaluation was considered as the most common type that was developed to investigate the potential efficiency of a textbook. The 'in-use' evaluation was designed to investigate material that was currently being used. Finally, the post-use or (retrospective) evaluation of a textbook that has been applied in any respective language institution.

Therefore, since the textbook has a great impact on the effectiveness of teaching and learning a foreign language, selecting the most appropriate one is worth considering and examining for both teachers and learners. Thus, in order to develop the process of language teaching and learning, an evaluation of textbook is needed. In this regard, the aim of this study was to evaluate the appropriateness of Egyptian primary schools "Connect 1" from the teachers' perspectives.

\section{Empirical Studies on Textbook Evaluation}

Due to the crucial role of textbook evaluation, many researchers have worked on examining the suitability of this issue. In order to evaluate different textbooks in different contexts, they tried to use various textbook evaluation schemes. For instance, in South Korea, Litz (2005) examined the appropriateness of "English Firsthand 2" textbook, which was taught at Sung Kyun Kwan University in Suwon, South Korea. In conclusion, he mentioned some advantages of this textbook, though, it is not a well-known textbook. For example, the entire textbook package has a variety of beneficial supplementary materials. It has a logical 


\section{on Teaching, Learning and Education}

and coherent organization. It also contains the integration of the four language skills (reading, listening, speaking, and writing).

In addition, it had the other important ELT elements such as vocabulary development. However, it failed to encourage meaningful and realistic practices. Generally, it failed to internalize the language. In another study, Tok (2010) investigated appropriateness of "Spot on" textbook which was used in state primary schools in Turkey. In this study, results have revealed some advantages and disadvantages. For advantages, he concluded that the teacher's guide books are highly useful. The content of the textbook has realistic, interesting, and motivating features, and also contains incorporating pair and group work. However, for disadvantages, he mentioned the low quality of design and layout of the textbook. He also claimed that the textbook activities do not reflect communicative purposes and meaningful practices.

Ansary (2004) evaluated the strengths and weaknesses of Iranian High school English textbooks. According to him, the designs of these textbooks are not attractive, usable, and durable. The other demerit is the little use of pictures and illustrations and thus they were not attractive for the students. In addition, the instructions of illustrations were not understandable. Moreover, in the reading parts, the background knowledge of the students was neglected and they were not organized according to their difficulty level.

Furthermore, Ghorbani (2011) investigated the appropriateness of "English Book 1" which was used in Iranian senior high schools. For this purpose, he created a new checklist. Results revealed that the book was found to have high physical qualities (such as paper quality, binding, printing, etc.). However, it lacks the integration of four language skills. There was not much attention to communicative tasks and activities. In addition, it failed to have reference materials such as audio CDs or student's and teacher's guides. The other weakness is that, there was not any glossary at the end of the book.

Ahour1, Towhidiyan1 and Saeidi (2014) in a quantitative study evaluated the merits and demerits of Iranian High schools "English Textbook 2" from the teachers' perspectives. In order to accomplish the purpose of this study, an adapted checklist (developed by Litz, 2005) was used. Generally, results have revealed that the overall teachers' perspectives toward this textbook were not favorable. The results of this study could be beneficial for syllabus and designers and materials developers in Ministry of Education. They suggested that it is better to revise it or adopt a new textbook.

Finally, in a more recent study, Rashidi and Kehtarfard (2014) investigated appropriateness of "English Book 3" which was used in Iranian high schools, by using the needs analysis questionnaires. Generally, they concluded that this textbook failed to integrate the four language skills (reading, listening, speaking, and writing). They suggested that materials developers and syllabus and curriculum designers should revise the current textbook. 


\section{on Teaching, Learning and Education}

Thus, taking these points into consideration, the main aim of the present research study was to examine the appropriateness of Egyptian first year primary textbook "Connect 1 " from the teachers' perspectives.

\section{Method}

In this section, some details related to the participants, instruments, procedures, data collection and analysis are explained.

\section{Design}

This study relied upon a survey-based quantitative design to meet its purposes. Hence, the researcher developed a questionnaire that was distributed among the participants. Results of responses to the questionnaire were measured quantitatively.

\section{Participants}

Thirty teachers were called for cooperation. These teachers had been teaching "Connect 1" for many years, hence experienced enough to be able to evaluate the books and identify their strengths and weaknesses. They were both males and females between 31-42 years of age and ranged from B.A. to Ph.D. holders. They were selected from different primary schools in Beni Suef, Egypt. The questionnaire was given to all the participants one by one, and they were asked to fill them out attentively. There was no time limit to complete the questionnaire, each teacher takes enough time to complete it according his/her experience. As the researcher believed that availability sampling could be a representative of the accessible and the target population; in the present research study, this type of sampling was used and thus participants were selected through availability sampling.

\section{Instruments}

The study used textbook content analysis and textbook evaluation questionnaire as instruments of the study.

\section{Textbook}

Since according to some teachers and students' attitudes, Connect 1 (among English textbooks of the primary school) was considered as the one which had more weaknesses; "Connect 1" was chosen as the textbook for the purpose of evaluation. This textbook which was approved by Ministry of Education in Egypt was used to teach English to first grade students in primary schools. Students in primary schools attended classes for learning this textbook three times a week (containing 2.25 hours).

\section{Content Analysis}

In order to evaluate the fitness of the material with the existing syllabus /curriculum, a content analysis checklist was developed and used. The checklist considers the fitness of the 


\section{on Teaching, Learning and Education}

course book with the syllabus /curriculum in its general aim, specific objectives, contents included, and mode of delivery.

\section{Textbook evaluation questionnaire}

The other instrument used in this study was a 5-point Likert scale questionnaire which considered 30 experienced teachers' viewpoints, Connect 1 mostly lacks the high quality of seven important criteria containing layout and design, subject and content, vocabulary, grammar, phonetics, activities, and skills. For the purpose of the current study, these parts containing 27 specific items were taken from this questionnaire. In addition, for the convenience of statistically coding, the questionnaire was simplified to Completely Disagree $=1$, Disagree $=2$, Moderately Agree $=3$, Agree $=4$, Completely Agree $=5$ (5-point Likert scale). Then, the content validity of the questionnaire was confirmed by three educational experts and four experienced teachers. In addition, the pilot study indicated the validity of the questionnaire for the context of Egypt. Likewise, for measuring internal reliability (consistency) of the items in the questionnaire, Cronbach Alpha coefficient was used and based on results value $(\alpha: .98)$, a very high internal consistency reliability obtained.

\section{Procedures}

For this study, the quantitative data were collected through the teacher textbook evaluation questionnaire. To this end, firstly the researcher has asked the permission from the teachers to participate. Then, data were generated through responses by 30 experienced English teachers to the textbook evaluation questionnaire. These teachers were selected randomly from various primary schools in Beni Suef, Egypt. Textbook evaluation questionnaire was administered at the first semester in the academic year 2019-2020. In order to collect the results of the current study, the researcher qualified its primary objectives before distributing the questionnaire. The findings were entered into the SPSS for later analysis. The descriptive statistics including mean, standard deviation, frequency, percentage were applied in the data analysis.

\section{Data collection}

In order to evaluate the textbook from teachers' viewpoints, data were collected at the end of the scholastic year. Before administering the questionnaires, the researcher explained the aim of the study and also the aims of each part and item of the questionnaire because she assumed it would help elicit real responses from the participants. In the next phase, for data collection a closed-ended questionnaire adapted from by Litz (2005) and Miekley (2005) was distributed to the participants. For the purpose of the current study, 27 particular questions were developed. Finally, to investigate the results, descriptive statistics were used.

To analyze the results obtained from the administered close-ended questionnaire, data were transformed to numeric results and descriptive statistics were applied through using the SPSS software (version 22.0). 


\section{Results}

The aim of this study was to evaluate the appropriateness of "Connect 1" of Egyptian primary school students from teachers' perspectives. Therefore, this section presents the results of the current study. The evaluation focuses on seven main criteria namely, 'layout and design, subject and content, vocabulary, grammar, phonetics, activities, and skills'.

The results of the study including means, standard deviations, frequencies, and percentages of items were estimated to summarize and describe the responses of teachers. The findings of each item that relate to a particular criterion are presented in tables and explanations are described accordingly

\section{Results of Data Analysis for Question 1}

Regarding the first question: "To what extent is the "Connect 1" appropriate for Egyptian primary school pupils in terms of layout and design?', teachers' responses to the first section (layout and design) of the questionnaire which contained two items were considered and results were estimated (see Table 1).

Table 1: Means, standard deviations, frequencies, and percentages of the items on layout and

\begin{tabular}{lcccccccccccccc}
\multicolumn{10}{c}{} & \multicolumn{10}{c}{ design } \\
\hline $\begin{array}{l}\text { Textbook } \\
\text { evaluation scales }\end{array}$ & & 1 & & 2 & & 3 & & 4 & & 5 & & & \\
\hline $\begin{array}{l}\text { Layout and } \\
\text { Design }\end{array}$ & $n$ & $\%$ & $n$ & $\%$ & $n$ & $\%$ & $n$ & $\%$ & $n$ & $\%$ & $M$ & $S D$ \\
\hline $\begin{array}{l}\text { Item 1 } \\
\text { Item 2 }\end{array}$ & 6 & 20 & 12 & 40 & 1 & 3.33 & 8 & 26.66 & 3 & 10 & 2.66 & 1.34 \\
\hline
\end{tabular}

Note: Completely Disagree $=1$, Disagree $=2$, Moderately Agree $=3$, Agree $=4$, Completely Agree $=5$

As a Table (1) indicates, almost more than half of the teachers $(60 \%)$ responded unfavorably to item $1(\mathrm{M}=2.66, \mathrm{SD}=1.34)$, and only $(36.66 \%)$ responded favorably to this item. They stated that the layout and design of the textbook were quite inappropriate for language learning processes.

For item 2, almost half of the teachers $(53.33 \%)$ responded unfavorably to this item $(\mathrm{M}=$ $2.83, \mathrm{SD}=1.34)$, while $(43.33 \%)$ responded favorably to it. They mentioned that the layout and design of the book need some reviewing and revision to be appropriate and effective.

\section{Results of the Data Analysis for Question 2}

Regarding the second research question: "To what extent is the "Connect 1" appropriate for Egyptian primary school pupils in terms of subject and content?', teachers' 


\section{on Teaching, Learning and Education}

responses to the first section (subject and content) of questionnaire which contained five items were considered and results were estimated (see Table 2).

Table 2: Means, standard deviations, frequencies, and percentages of the items on subject

\begin{tabular}{|c|c|c|c|c|c|c|c|c|c|c|c|c|}
\hline \multicolumn{13}{|c|}{ and content } \\
\hline $\begin{array}{l}\text { Textbook } \\
\text { evaluation scales }\end{array}$ & & 1 & & 2 & & 3 & & 4 & & 5 & & \\
\hline $\begin{array}{l}\text { Subject and } \\
\text { Content }\end{array}$ & $n$ & $\%$ & $n$ & $\%$ & $n$ & $\%$ & $n$ & $\%$ & $n$ & $\%$ & $M$ & $S D$ \\
\hline Item 3 & 15 & 50 & 8 & 26.66 & 4 & 13.33 & 1 & 3.33 & 1 & 3.33 & 1.73 & 1.03 \\
\hline Item 4 & 18 & 60 & 7 & 23.33 & 2 & 6.66 & 1 & 3.33 & 2 & 6.66 & 1.73 & 1.17 \\
\hline Item 5 & 2 & 6.66 & 16 & 53.33 & 4 & 13.33 & 6 & 20 & 1 & 3.33 & 2.50 & 1.00 \\
\hline Item 6 & 9 & 30 & 12 & 40 & 5 & 16.66 & 3 & 10 & 1 & 3.33 & 2.16 & 1.08 \\
\hline Item 7 & 5 & 16.66 & 13 & 43.33 & 8 & 26.66 & 2 & 6.66 & 2 & 6.66 & 2.43 & 1.06 \\
\hline
\end{tabular}

Note: Completely Disagree $=1$, Disagree $=2$, Moderately Agree $=3$, Agree $=4$, Completely Agree $=5$

As Table 2 indicates, almost two third of the teachers $(76.66 \%)$ responded unfavorably to item $3(\mathrm{M}=1.73, \mathrm{SD}=1.03)$. They stated that the subject and content of the textbook did not correspond to pupils' needs and educational purposes.

For item 4 , a large number of the teachers $(83.33 \%)$ responded unfavorably to this item $(\mathrm{M}=$ $1.73, \mathrm{SD}=1.17)$. They stated that the textbook subject and content was not generally realistic.

Item 5 shows that, almost more than half of the teachers $(60 \%)$ believed that the textbook subject and content was not interesting, challenging, and motivating $(\mathrm{M}=2.5, \mathrm{SD}=1.00)$.

According to item 6 , most of the teachers $(70 \%)$ responded unfavorably to this item $(\mathrm{M}=$ $2.16, \mathrm{SD}=1.08)$. They stated that there is not sufficient variety in the subject and content of the textbook.

As Table 2 indicates, while more than half of the teachers $(60 \%)$ responded unfavorably to item $7(\mathrm{M}=2.43, \mathrm{SD}=1.06)$, only $13.33 \%$ stated that materials are not culturally biased and do not portray any negative stereotypes.

\section{Results of the Data Analysis for Question 3}

Regarding the third research question: "To what extent is the "Connect 1" appropriate for Egyptian primary school pupils in terms of vocabulary', teachers' responses to the third part (vocabulary) of the questionnaire which contained three items were measured and results were estimated (see Table 3). 


\section{on Teaching, Learning and Education}

Table 3: Means, standard deviations, frequencies, and percentages of the items on vocabulary

\begin{tabular}{lccccccccccccc}
\hline $\begin{array}{l}\text { Textbook } \\
\text { evaluation scales }\end{array}$ & \multicolumn{3}{c}{1} & \multicolumn{2}{c}{2} & \multicolumn{3}{c}{3} & \multicolumn{3}{c}{4} & \multicolumn{3}{c}{5} \\
\hline Vocabulary & $n$ & $\%$ & $n$ & $\%$ & $n$ & $\%$ & $n$ & $\%$ & $n$ & $\%$ & $M$ & $S D$ \\
\hline Item 8 & 9 & 30 & 14 & 46.66 & 3 & 10 & 2 & 6.66 & 2 & 6.66 & 2.13 & 1.13 \\
Item 9 & 19 & 63.33 & 7 & 23.33 & 2 & 6.66 & 1 & 3.33 & 1 & 3.33 & 1.60 & 1.00 \\
Item 10 & 5 & 16.66 & 12 & 40 & 4 & 13.33 & 7 & 23.33 & 2 & 6.66 & 2.63 & 1.15 \\
\hline
\end{tabular}

Note: Completely Disagree $=1$, Disagree $=2$, Moderately Agree $=3$, Agree $=4$, Completely Agree $=5$

As Table 3 indicates, almost two third of the teachers $(76.66 \%)$ responded unfavorably to item $8(\mathrm{M}=2.13, \mathrm{SD}=1.13)$. They stated that vocabulary items of the textbook were not appropriate and beneficial for pupils' age level.

Item 9 shows that, a vast majority of the teachers $(86.66 \%)$ believed that vocabulary items of the textbook were not shown in sequence from simple to complex $(\mathrm{M}=1.60, \mathrm{SD}=1.00)$.

According to item 10, more than half of the teachers $(56.66 \%)$ responded unfavorably to this item $(\mathrm{M}=2.63, \mathrm{SD}=1.15)$. They stated that vocabulary items of the textbook were not realistic and not related to every day words. $30 \%$ stated that vocabulary items of the textbook were realistic and not related to every day words.

\section{Results of the Data Analysis for Question 4}

Regarding the third research question: "To what extent is the "Connect 1" appropriate for Egyptian primary school pupils in terms of grammar?', teachers' responses to the fourth part (grammar) of the questionnaire which contained two items were measured and results were estimated (see Table 4).

Table 4: Means, standard deviations, frequencies, and percentages of the items on grammar

\begin{tabular}{lcccccccccccc}
\hline $\begin{array}{l}\text { Textbook } \\
\text { evaluation scales }\end{array}$ & \multicolumn{2}{c}{1} & & 2 & & 3 & & 4 & & 5 & & \\
\hline Grammar & $n$ & $\%$ & $n$ & $\%$ & $n$ & $\%$ & $n$ & $\%$ & $N$ & $\%$ & $M$ & $S D$ \\
\hline Item 11 & 11 & 36.66 & 14 & 46.66 & 3 & 10 & 1 & 3.33 & 1 & 3.33 & 2.13 & 0.98 \\
Item 12 & 9 & 30 & 13 & 43.33 & 4 & 13.33 & 2 & 6.66 & 2 & 6.66 & 2.16 & 1.14 \\
\hline
\end{tabular}

Note: Completely Disagree $=1$, Disagree $=2$, Moderately Agree $=3$, Agree $=4$, Completely Agree $=5$ 


\section{3rd International Academic Conference on Teaching, Learning and Education}

As Table 4 indicates, majority of the teachers $(83.33 \%)$ responded unfavorably to item 11 (M $=2.13, \mathrm{SD}=0.98)$. They stated that grammar of the textbook were not simple and inappropriate for pupils' age level.

According to item 12 , most of the teachers $(73.33 \%)$ responded unfavorably to this item $(\mathrm{M}=$ $2.16, \mathrm{SD}=1.14)$. They stated that teaching grammar inductively is not appropriate method for this age level.

\section{Results of the Data Analysis for Question 5}

Regarding the third research question: "To what extent is the "Connect 1" appropriate for Egyptian primary school pupils in terms of phonetics?', teachers' responses to the fifth part (phonetics) of the questionnaire which contained three items were measured and results were estimated (see Table 5).

Table 5: Means, standard deviations, frequencies, and percentages of the items on phonetics

\begin{tabular}{lccccccccccccc}
\hline $\begin{array}{l}\text { Textbook } \\
\text { evaluation scales }\end{array}$ & \multirow{2}{*}{1} & \multicolumn{2}{c}{2} & & 3 & & & & 5 & & \\
\hline Phonetics & $n$ & $\%$ & $n$ & $\%$ & $n$ & $\%$ & $n$ & $\%$ & $N$ & $\%$ & $M$ & $S D$ \\
\hline Item 13 & 9 & 30 & 14 & 46.66 & 3 & 10 & 3 & 10 & 1 & 3.33 & 2.30 & 1.08 \\
Item 14 & 2 & 6.66 & 17 & 56.66 & 7 & 23.33 & 3 & 10 & 1 & 3.33 & 2.46 & 0.89 \\
Item 15 & 20 & 66.66 & 7 & 23.33 & 2 & 6.66 & 1 & 3.33 & - & - & 1.46 & 0.77 \\
\hline
\end{tabular}

Note: Completely Disagree $=1$, Disagree $=2$, Moderately Agree $=3$, Agree $=4$, Completely Agree $=5$

As Table 5 indicates, almost two third of the teachers $(76.66 \%)$ responded unfavorably to item $13(\mathrm{M}=2.30, \mathrm{SD}=1.08)$. They stated that sequencing of showing the sounds in the textbook were not logic or appropriate.

Item 14 shows that, more than half of the teachers $(63.33 \%)$ believed that comparison between similar and different sounds was not a good idea in this age level $(\mathrm{M}=2.46, \mathrm{SD}=$ $0.89)$.

According to item 15, a vast majority of the teachers (90\%) responded unfavorably to this item $(\mathrm{M}=1.46, \mathrm{SD}=0.77)$. They stated that vocabulary items of the textbook were not realistic and not related to every day words. $30 \%$ stated that the textbook did not provide pupils with the sounds of letters systematically. 


\section{on Teaching, Learning and Education}

\section{Results of the Data Analysis for Question 6}

Regarding the third research question: "To what extent is the "Connect 1" appropriate for Iranian high school students in terms of activities?', teachers' responses to the sixth part (activities) of the questionnaire which contained seven items were measured and results were estimated (see Table 6).

Table 6: Means, standard deviations, frequencies, and percentages of the items on activities

\begin{tabular}{|c|c|c|c|c|c|c|c|c|c|c|c|c|}
\hline $\begin{array}{l}\text { Textbook } \\
\text { evaluation scales }\end{array}$ & & 1 & & 2 & & 3 & & 4 & & 5 & & \\
\hline Activities & $n$ & $\%$ & $n$ & $\%$ & $N$ & $\%$ & $n$ & $\%$ & $N$ & $\%$ & $M$ & $S D$ \\
\hline Item 16 & 10 & 33.33 & 13 & 43.33 & 2 & 6.66 & 3 & 10 & 2 & 6.66 & 2.13 & 1.19 \\
\hline Item 17 & 14 & 46.66 & 10 & 33.33 & 3 & 10 & 2 & 6.66 & 1 & 3.33 & 1.86 & 1.07 \\
\hline Item 18 & 11 & 36.66 & 11 & 36.66 & 4 & 13.33 & 3 & 10 & 1 & 3.33 & 2.06 & 1.11 \\
\hline Item 19 & 8 & 26.66 & 14 & 46.66 & 2 & 6.66 & 4 & 13.33 & 2 & 6.66 & 2.26 & 1.20 \\
\hline Item 20 & 9 & 30 & 16 & 53.33 & 2 & 6.66 & 1 & 3.33 & 2 & 6.66 & 2.03 & 1.06 \\
\hline Item 21 & 13 & 43.33 & 10 & 33.33 & 4 & 13.33 & 2 & 6.66 & 1 & 3.33 & 1.93 & 1.08 \\
\hline Item 22 & 9 & 30 & 11 & 36.66 & 6 & 20 & 3 & 10 & 1 & 3.33 & 2.20 & 1.20 \\
\hline
\end{tabular}

Note: Completely Disagree $=1$, Disagree $=2$, Moderately Agree $=3$, Agree $=4$, Completely Agree $=5$

Item 16 shows that, a huge number of the teachers $(76.66 \%)$ believed that the textbook did not provide a balance of activities and the exercises could not provide opportunities for learners to improve their language proficiency including their accuracy and fluency $(\mathrm{M}=$ $2.13, \mathrm{SD}=1.19)$.

For item 17 , most of the teachers $(80 \%)$ responded unfavorably to this item $(\mathrm{M}=1.86$, $\mathrm{SD}=1.07)$. They stated that the textbook activities did not correspond to the students' communicative purposes.

According to item 18, whereas most of the teachers completely disagreed and disagreed (73.33\%) with the appropriateness of the textbook activities in terms of individual, pair, and group work; $33.8 \%$ of them agreed with this item $(\mathrm{M}=2.06, \mathrm{SD}=1.11)$.

For item 19 , majority of the teachers $(73.33 \%)$ responded unfavorably to this item $(\mathrm{M}=2.26$, $\mathrm{SD}=1.20$ ). They claimed that since the textbook activities were not motivating and did not contain realistic contents, they could not correspond to the students' educational needs in terms of learning through grammar points and vocabularies of the textbook. 


\section{on Teaching, Learning and Education}

29-31 July, 2021

As item 20 indicates, most of the teachers $(83.33 \%)$ responded unfavorably to this item $(\mathrm{M}=$ $2.03, \mathrm{SD}=1.06)$. They stated that the textbook activities did not promote creative, original, and independent responses.

Item 21 indicates that, a large number of the teachers $(76.66 \%)$ responded unfavorably to this item $(\mathrm{M}=1.93, \mathrm{SD}=1.08)$. They stated that the tasks of the textbook were not conducive to the introduction of newly introduced language and argued that the tasks were not introduced in meaningful situations to facilitate understanding.

As Table 6 indicated, while two third of the teachers $(66.66 \%)$ responded unfavorably to item $22,47.6 \%$ of the teachers stated that activities of this textbook can be modified or supplemented easily $(\mathrm{M}=2.20, \mathrm{SD}=1.20)$.

\section{Results of the Data Analysis for Question 7}

Regarding the last research question: "To what extent is the "Connect 1" appropriate for Egyptian primary school pupils in terms of language skills?', teachers' responses to the seventh section (language skills) of the questionnaire which contained five items were considered and results of them were estimated (see Table 7).

Table 7: Means, standard deviations, frequencies, and percentages of the items on skills

\begin{tabular}{lcccccccccccc}
\hline $\begin{array}{l}\text { Textbook } \\
\text { evaluation scales }\end{array}$ & \multicolumn{3}{l}{1} & \multicolumn{2}{c}{2} & & 3 & & 4 & & & \\
\hline Skills & $n$ & $\%$ & $n$ & $\%$ & $n$ & $\%$ & $n$ & $\%$ & $N$ & $\%$ & $M$ & $S D$ \\
\hline Item 23 & 7 & 23.33 & 12 & 40 & 8 & 26.66 & 2 & 6.66 & 1 & 3.33 & 2.26 & 1.01 \\
Item 24 & 6 & 20 & 16 & 53.33 & 4 & 13.33 & 2 & 6.66 & 2 & 6.66 & 2.26 & 1.08 \\
Item 25 & 2 & 6.66 & 18 & 60 & 7 & 23.33 & 1 & 3.33 & 2 & 6.66 & 2.43 & 0.93 \\
Item 26 & 17 & 56.66 & 2 & 6.66 & 5 & 16.66 & 2 & 6.66 & 2 & 6.66 & 1.80 & 1.29 \\
Item 27 & 13 & 43.33 & 12 & 40 & 2 & 16.66 & 2 & 20 & 1 & 3.33 & 1.86 & 1.04 \\
\hline
\end{tabular}

Note: Completely Disagree $=1$, Disagree $=2$, Moderately Agree $=3$, Agree $=4$, Completely Agree $=5$

For item 23 most of the teachers $(63.33 \%)$ responded unfavorably to this item $(\mathrm{M}=2.26, \mathrm{SD}$ $=1.01)$. They declared that materials did not include the skills which could improve pupils' language learning process.

Item 24 shows that, majority of the teachers $(73.33 \%)$ believed that the textbook did not provide an appropriate balance of the four language skills $(\mathrm{M}=2.26, \mathrm{SD}=1.08)$.

According to item 25, almost two third of the teachers $(66.66 \%)$ responded unfavorably to this item $(\mathrm{M}=2.43, \mathrm{SD}=0.93)$. They stated that the materials did not include sufficient and suitable sub-skills. 
As Table 7 indicates, more than half of the teachers $(63.33 \%)$ responded unfavorably to item $26(\mathrm{M}=1.80, \mathrm{SD}=1.29)$. They claimed that the textbook did not contain natural pronunciation tasks and practices.

Item 27 shows that, majority of the teachers $(83.33 \%)$ believed that the practice of the individual skills was not integrated into the practice of other skills. Therefore, meaningful communication was not promoted by referring to realistic skills and activities $(\mathrm{M}=1.86, \mathrm{SD}$ $=1.04)$.

\section{Discussion}

Material evaluation helps researchers, teachers, and learners to look inside the materials and therefore be able to control their design and usage (Littlejohn, 2011). For the purpose of this study, the appropriateness of "Connect 1" was investigated according to 30 teachers' attitudes in terms of four seven criteria (layout and design, subject and content, vocabulary, grammar, phonetics, activities, and skills) of a textbook evaluation questionnaire adapted from Litz (2005) and Miekley (2005).

According to teachers' beliefs, the layout and design of the textbook was not established appropriately. For instance, teachers stated that the textbook did not contain suitable warm-up activities, listening and speaking tasks failed to persuade students for communicating successfully. Another shortcoming was that the vocabulary and grammar points were not designed effectively. The results generated through responses to this section contradicted with the findings of Litz (2001) who investigated the appropriateness of "English Firsthand 2", and findings of Shabani \& Safari (2017) who investigated "English Textbook 2" for Iranian high school students.

As regards evaluating the subject and content of the textbook, the findings including means and standard deviations indicated that most of the teachers were not satisfied with the textbook subject and content. Based on a vast majority of the teachers, the subject and content of the textbook were not relevant to the students' needs, were not motivating and interesting, and did not contain realistic features and sufficient varieties. However, the highest mean (2.50) in the 'Subject and Content' part was related to the item 5. In responding to this item, almost more than half of the teachers believed that materials were not interesting, challenging, and motivating. In this regard, the findings of this study were in agreement with the work of Ahour, Towhidiyan, and Saeidi (2014).

In the third part 'evaluating vocabulary items of the textbook', the findings including means and standard deviations indicated that most of the teachers were not satisfied with the vocabulary. Based on a vast majority of the teachers, the vocabulary items of the textbook were not appropriate or beneficial for student's age level, were not shown in sequence from simple to complex, and were not items are realistic and related to every day words. However, the highest mean (2.63) in the 'Vocabulary' part was related to the item 10. In responding to this item, almost more than half of the teachers believed that realistic and related to every day 


\section{3rd International Academic Conference on Teaching, Learning and Education}

words, while $30 \%$ stated that vocabulary items of the textbook were realistic and not related to every day words. In this regard, the findings of this study were in agreement with the work of Riasati and Zare (2010).

Regarding evaluating the grammar of the textbook, the findings indicated that most of the teachers were not satisfied with the textbook grammar. Based on a vast majority of the teachers, the grammar of the textbook were not adequate simple to be suitable for pupils' age level, and teaching grammar inductively were not the most appropriate method for this age level. In this regard, the findings of this study were in agreement with the work of Ahour, Towhidiyan, and Saeidi (2014).

According to the teachers' beliefs, the phonetics of the textbook was not established effectually. For instance, teachers stated that the textbook did not show sequencing the sounds of letters logically and appropriately, and did not provide pupils with the sounds of letters systematically. Another shortcoming was that the comparison between similar and different sounds is not an effective method in this age level according to the opinion of majority teachers. The results generated through responses to this section contradicted with the findings of Shabani \& Safari (2017).

According to the results obtained from the "activities" part, most of the teachers responded unfavorably to the items of this section. The findings indicated that the textbook did not provide a balance of activities which could help language learners to be more fluent and accurate. They claimed that the activities could not encourage sufficient communicative meaningful tasks and could not incorporate individual, pair, and group work. However, according to many scholars such as Widdowson (1983) and Grant (1987), in order to help students to be able to communicate and speak in the target language, any language activity and program should contain useful and meaningful communicative tasks and activities. Moreover, teachers mentioned that grammar points and vocabulary items were not introduced in motivating and realistic contexts. They also stated that the textbook activities could not promote creative, original, and independent responses. In addition, they believed that the tasks were conductive to the internalization of newly introduced language. On the other side, according to more than half of the teachers' viewpoints, textbook activities could be modified or supplemented easily. Regarding section "activities", while findings of the items 16, 17, 18, 19, 20 and 21 contradicted with the work of Riasati and Zare (2010), results of the last item (22) of this section were in line with the work of theses researchers (Riasati \& Zare, 2010). Moreover, the findings of this section were in line with the works' of Ansary (2004) and Ahour, Towhidiyan, and Saeidi (2014).

With respect to the last part "skills", means and standard deviations of the outcomes showed that majority of the teachers disagreed on the appropriateness of Connect 1 . According to teachers' perspectives, results revealed that the textbook did not include and focus on the skills that the students need to improve their language. In addition, they claimed that the textbook did not establish an appropriate balance of the four basic language skills and there was not much attention to sub-skills. Furthermore, teachers stated that the textbook did 


\section{on Teaching, Learning and Education}

not highlighted natural pronunciation. Finally, according to most of the instructors, the practice of individual skills was not integrated into the practice of other skills. The results of this study regarding the "skills" section were in agreement with the findings of many researchers such as Ansary (2004), Ghorbani (2011), and Ahour, Towhidiyan, and Saeidi (2014). On the other hand, the results of the "skills" section of the current study contradicted with the findings of Riasati and Zare (2010) who evaluated the appropriateness of New Interchange Series.

\section{Conclusions}

Considering the fact that textbooks establish the basic materials for a languagelearning course (Tomlinson, 2011), investigating their appropriateness and then selecting the most suitable ones are essential. Additionally, textbooks in most language learning classes of Egypt are considered as the main source for both teaching and learning processes. To this end, the aim of the present research was to evaluate the appropriateness of Connect 1 . According to the results, there were much more demerits than merits regarding evaluating the appropriateness of "Connect 1". Based on the teachers' perspectives, the subject and content of the book including vocabulary, grammar, and phonetics failed to correspond to teachers' and learners' needs. Furthermore, textbook design, tasks, activities, and exercises could not encourage and persuade students for improving language and especially communicative purposes.

In addition, although according to Cunnigsworth (1995) the English textbooks should cover all the four skills, this textbook lacked the integration of the four language skills. Although many scholars such as Celce-Murcia (2001) declared that the textbooks should correspond to the students' needs, the findings of the current study indicated that "Connect 1" could not match with students' educational purposes. Therefore, "Connect 1" was not appropriate for Egyptian primary school students in terms of layout and design, subject and content, vocabulary, grammar, phonetics, activities, and skills.

Based on the findings of the current study, in order to accomplish the students' preferences and needs, the layout and design of the "Connect 1" should be organized more effectively and contain various useful language learning techniques. Furthermore, the subject and content of the book, vocabulary, grammar, and phonetics should be modified. In addition, since according to Cunningsworth (1995) textbooks should match with the language learners' needs and interests, there should be interesting topics, content varieties, and useful skills and sub-skills for encouraging students to proceed with their language learning objectives. In conclusion, the findings of this study would be beneficial for materials developers, evaluators, and syllabus and curriculum designers especially for those working in the Ministry of Education. This study also suggests that it is better to conduct a new textbook for the first-grade primary school or at least reconsider the current textbook according to the mentioned items in the study. 


\section{on Teaching, Learning and Education}

29-31 July, 2021

\section{References}

Abdelwahab, M. M. (2013). Developing an English Language Textbook Evaluative Checklist. JOSR Journal of Research \& Method in Education, 1(3), 55-70.

Ahour, T., \& Ahmadi, E. (2012). Retrospective evaluation of textbook "Summit 2B" for its suitability for EFL undergraduate students. Journal of Educational and Social Research, 2(5), 195-202.

Ahour, T., Towhidiyan, B., \& Saeidi, M. (2014). The evaluation of "English Textbook 2" taught in Iranian high schools from teachers' perspectives. English Language Teaching, 7(3), 150.

Ansary, T. (2004). An analytic look at high school English textbook and introducing a sample lesson based on communicative syllabus design (Unpublished master's thesis, Islamic Azad University-Tabriz Branch, Iran).

Birjandy, P., Noroozi, M., \& Mahmoodi, G. (2012). English Book 2. Tehran: Textbook Publishing Company of Iran.

Celce-Murcia, M. (2001). Teaching English as a second or foreign language (3rd ed). Boston: Heinle \& Heinle.

Cunningsworth, A. (1995). Choosing your coursebook. Oxford: Heinemann Publishers Ltd. Davison.

Dudley-Evans, T., \& St John, M. G. (2005). Developments in English for specific purposes: A multi-disciplinary approach. Cambridge: Cambridge University Press.

Ellis, R. (1997). SLA research and language teaching. Oxford: Oxford University Press.

Garinger, D. (2001). Textbook evaluation. TEFL Web Journal. Retrieved from http://www.teflwebj.org/v1n1/garinger.html

Garinger, D. (2002). Textbook selection for the ESL classroom. Center for Applied Linguistics Digest.

Ghorbani, M. R. (2011). Quantification and graphic representation of EFL textbook evaluation results. Theory and Practice in Language Studies, 1(5), 511-520. http://dx.doi.org/10.4304/tpls.1.5.511-520

Grant, M. (1987). Making the most of your textbook. London: Longman. 


\section{3rd International Academic Conference on Teaching, Learning and Education}

29-31 July, 2021

Hutchinson, T. (1987). What's underneath? An interactive view of materials evaluation. In L. E. Sheldon (Ed.), ELT course books and materials: Problems in evaluation and development, ELT Documents (p. 126). London: Modern English publications. The British Council.

Hutchinson, T., \& Waters, A. (1993). English for specific purposes: A learning-centered approach. Cambridge: Cambridge University Press.

Littlejohn, A. (2011). The analysis of language teaching materials: Inside the Trojan Horse. In B. Tomlinson (Ed.), Materials development in language teaching (pp. 179-211). Cambridge: Cambridge University Press

Litz, D.R.A. (2001). Textbook evaluation and ELT management: A South Korean case study. Retrieved July, 2015 from http://www.pdfgeni.com.

Litz, D. R. A. (2005). Textbook evaluation and ELT management: A South Korean case study. Asian EFL Journal. Retrieved November 12, 2012, from http://www.asianefljournal.com/Litz_thesis.pdf

McDonough, J., \& Shaw, C. (2003). Materials and methods in ELT: A teacher's guide (2nd ed.). Oxford: Blackwell Publishing.

Miekley, J. (2005). ESL Textbook Evaluation Checklist, The Reading Matrix Vol. 5, No. 2, .

Nunan, D. (1999). Second language teaching and learning. Boston: Heinle and Heinle.

Prabhu, N.S. (1987). Second language pedagogy. Oxford: Oxford University Press.

Rashidi, N., \& Kehtarfard, R. (2014). A needs analysis approach to the evaluation of Iranian third-grade high school English textbook. Sage Publication, 4(3), 1-9.

Razmjoo, S. A. (2010). Developing a textbook evaluation scheme for the expanding circle. Iranian Journal of Applied Language Studies, 2(1), 121-136.

Riasati, M. J., \& Zare, P. (2010). EFL teachers' perspectives on "New Interchange". Studies in Literature and Language, 1(8), 54-60.

Riazi, A. M. (2003). "What Textbook Evaluation Schemes Tel Us? A study of the textbook evaluation schemes of three decades", in W. A. Renanda. (ed.), Methodology and Materials Design in Language Teaching, Singapore (pp. 52-68). SEAMEO Regional Center. 


\section{on Teaching, Learning and Education}

Richards, J. C. (2001). Curriculum development in language teaching. Cambridge: Cambridge University Press. 28. Sheldon, L. E. (1988). Evaluating ELT textbooks and materials. ELT Journal, 42, 237-246. http://dx.doi.org/10.1093/elt/42.4.237

Shabani, K. \& Safari, F. (2017). Evaluation of Iranian Second-Grade High School English Textbook from Teachers' Perspectives, Bulletin de la Société Royale de Liège, Vol. 86, special issue, 2017, p. 111 - 126

Tok, H. (2010). TEFL textbook evaluationn: From teachers' perspectives. Educational Research and Review, 5(9), 508-517. 